\title{
English Department Students' Anxiety in Interacting Orally with an English Native Speaker Lecturer
}

\author{
WINI APRILIA MARDJANI \\ Universitas Negeri Gorontalo \\ winiaprilia91@gmail.com
}

\begin{abstract}
Anxiety has a debilitating effect on the oral interaction of English Department students with English native speaker (ENS) lecturer. Thus, the present study seeks to discover the perceived factors that cause anxiety among students in interacting with ENS lecturer in the classroom. Informed by a qualitative approach, data were collected mainly using group semi-structured interviews, and analyzed using a thematic analysis approach. The study revealed that the English Department students reported four perceived factors, namely,; limited English proficiency, fear of being misunderstood, lack of self-confidence, and fear of negative evaluation. The study suggests that even though ENS has minor influence in students' anxiety, it remains important for teacher and teacher educators to continuously encourage students to practice speaking English in and off classroom situation.
\end{abstract}

Keywords: anxiety; perceived factor; ENS lecturer; interaction

\section{INTRODUCTION}

Anxiety is a feeling where someone feels fear and loss of confidence (Wiramihardja, 2005). Stocker (2013) stated that there are several symptoms of anxiety. Those are tension, always expect danger, trembling, shivering or sweating, lack of concentration and focus, and feels like it is never enough. Those symptoms often occur when students were asked to show their performance in English. MacIntyre and Gardner (1994) defined anxiety as a feeling of tension and apprehension specifically when it is associated with second language context, including speaking, listening, and learning. For example, when a student speaks English in front of the class, the student might feel nervous or afraid which prevent the students from speaking English properly. Generally, students will feel afraid when they are speaking which is mainly caused by lacking of vocabulary or unable to pronounce the words correctly. This feeling is very prominent in terms of speaking and often occurs in classroom.

In English Department, Faculty Letters and Culture at the Universitas Negeri Gorontalo, there was a native speaker who taught students throughout the fourth semester. Based on the information obtained from these students, they learnt about writing and speaking as the subject in the fourth semester. They also pointed out that they were afraid to ask a question and stayed silent even when the native speaker opened the question session. Therefore, this study intends in discovering the factors that cause students' anxiety when interacting with an English native speaker in the classroom, in the context of English Education Program in Gorontalo, Indonesia. 


\section{LITERATURE REVIEW FOREIGN LANGUAGE ANXIETY}

Foreign language anxiety is defined as the uniqueness of language learning process that stimulates complex self-perceptions, beliefs, feelings, and behavior related to classroom language learning (Horwitz, Horwitz and Cope, 1986). It is a complex construct that deals with learners' psychology in terms of their feelings, self-esteem, and self-confidence (Clement, 1980). Maclntyre and Gardner (1991) stated that FLA is described as the feeling of tension and apprehension specifically associated with second or foreign language context, including speaking and listening, or the worry and negative emotional reaction when learning or using a second or foreign language. Foreign language anxiety, in short, is signified by psychological symptoms, such as loss of confidence and worry that rises when learning a foreign language.

Foreign language anxiety can affect language learners negatively. Onwuegbuzie, Bailey, Christine and Daley (1999) as cited in Mahmoodzadeh (2012) stated that the existence of foreign language anxiety can set out a negative effect on the learners' speech and learning in a general sense. Also FLA is defined as a tension related to the fields of the second language, including speaking and listening (Maclntyre and Gardner, 1994). It is similar with Ozturk and Gurbuz (2014) who wrote in their study that students in foreign language classroom usually report that speaking in a target language gives the most anxiety experience. It seems that speaking skill is limited by anxiety. Thus, foreign language anxiety triggers the emergence of speaking anxiety that could affect the speaking skill which is needed to learn a foreign language.

\section{NATIVE AND NON-NATIVE ENGLISH TEACHERS}

A native speaker is a person who learned to speak a language as part of their development. Davies (1991) stated that native speaker is the individual acquired the language in early childhood. Native speaker is person who has deep knowledge and control of their language, for instance, they know about the things whether can be included or not be included in the supposed language (Davies, 2003). It looks like that the native speaker is the stakeholder of the language.

Also, native speaker often become language teachers in other countries, such as Indonesia. Obviously, this gives an impact to the students who learn English as a foreign language. Hence, there are differences between native and non-native English teachers and the main point is in the learning process. As Gurkan and Yuksel (2012) found, non-native English teachers are better at understanding the difficulties that are faced by their students. They are also identified to provide a better learning strategy. However, English native speakers are better at providing consistent language models, show a greater adaptability and also exhibit their own dialects in during the teaching process. Correspondingly, they are better at pronunciation and give the students a unique sensation of being exposed to the foreign cultures, in this case, English.

Therefore, students feel more anxious when they have an English native speaker as teacher. Maclntyre and Gardner (1994) believed that an environment where multi-cultural and foreign speakers exist might increase the anxiety level of students. Similarly, Bozavli and Gulmez (2012) found that students in native speaker class were more anxious than those in non-native speaker class.

In brief, English native speaker teacher is not the only cause of the students' anxiety but also the method of teaching that can be applied as well as a supporting factor, such as, environment in learning. Then, below is the section about English language teaching in Indonesia. 


\section{ENGLISH LANGUAGE TEACHING}

English language teaching in Indonesia mostly tends to be teacher-centered. Mbato (2013) stated that teaching English in Indonesia is teacher-centered and teacher directed, with a heavy emphasis on following the curriculum and testing. Based on the phenomenon, although the government has replaced the curriculum from curriculum of 2004 to curriculum of 2013, the teaching model in the classroom still makes the teacher as the center. It means that during the learning process, the teacher are more active than students. Also Lengkanawati (2004) found that Indonesian students use memory strategies and less cognitive strategies and also, the classroom is not very active. Moreover, Mbato (2013) stated that there are three reasons for the limited effectiveness of English foreign language learning and teaching in Indonesia. First, EFL learning mostly occurs in classroom context. Second, the only source of learning is from the teachers and learning materials provided in class. Third, students learn English because it is a compulsory part of curriculum.

However, schools and universities in Indonesia teach English to help its students to get access better jobs in the future. Particularly, students, who chose English department as their major, are expected to master English because as the name suggest, most of the courses used and related to English. Unfortunately, there is still a group of students in English Department who display lack of vocabulary nor unable to use correct grammar, thus cannot use English to communicate outside of the classroom. It also becomes the challenge for the lecturer, as stated by Abid (2018) who claimed that lecturer has difficulties in spoken second language in oral communication in and out of the classroom because the use of first language is dominant in some ways. Also Machmud and Abdulah (2017) thought that the main problem in teaching English as foreign language is the limited time and the large class size.

\section{METHOD}

This research used a qualitative method. Ghony \& Almanshur (2017) defined qualitative method as investigating certain social situations by describing reality in correctly, formed by words based on the techniques of collecting and analyzing relevant data that is obtained from natural situation. The participants of this research were the students of English Department.

The research focused on the interaction between native speaker lecturer and the sixth-semester students of 2016 which consists of five classes, namely, class A to class E. The English native speaker has taught English Department students for two years and ended in 2018. The English native speaker taught two subjects in two classes, that is, class A for speaking and class E for writing. However, the researcher took class E purposively, which consists of fifteen students because the interaction between students and English native speaker is more established and supported by natural setting. It means that they are not pressured to speak up in the classroom. While in speaking class, speaking or interacting orally is a must. On the other hand, oral interaction of active and passive students is more visible in the writing class.

Semi-Structure interview was carried out in order to get in depth information about the factors that caused speaking anxiety of students when interacting with English native speaker. To analyze the data, a thematic analysis approach was used. Participants' responses arising from the interviews were grouped and assigned with various codes. These codes were further analyzed and grouped to elicit themes that addressed the research question. 


\section{FINDINGS AND DISCUSSION}

Findings are presented under the following themes: (1) Limited English proficiency; (2) Fear of being misunderstood; (3) Lack of self-confidence; (4) Fear of negative evaluation. Following the presentation of each finding is the discussion. In the findings section, quote from participants are included as evidence to support each finding. At the end of each quote, there is a sign in brackets, which details who owns the quote and the page of the interview transcript from which the quote is taken. English translations are given following each quote written in Indonesian (in italics).

\section{LIMITED ENGLISH PROFICIENCY}

For the purpose of this study, English proficiency is composed of several aspects of language skills, such as grammar, pronunciation, and vocabulary that put stress on the students if they accidentally made a mistake when interacting with an English native speaker lecturer. Student1 (Stud1), for example, stated that she was afraid when interacting with an English native speaker lecturer (ENSL) in the classroom because lack of vocabulary:

Kalo saya ada sedikit rasa takut karna ee.. vocab yang saya miliki itu emm.. Masih sedikit belum terlalu ini.. (Stud1:23)

I have anxiety because ee.. the vocabulary that I have emm.. It's still not much.. (Researchers' translation, Stud1:23)

Stud5 added that he was forgotten about vocabularies when he wants to interact with ENSL in the classroom:

Kalo saya vocab kak, kalo mau bercerita dengan miss rasanya saya so tidak tau apa yang mau dibilang, so lupa-lupa dengan vocab (Stud5:35)

It causes of vocabulary, if I want to talk with Miss, I feel like I do not know what to say, I was forgotten (Researchers' translation, Stud5:35)

In addition, Stud2 reported that she was nervous because of her grammar mess up when interact with an ENSL even she had prepared before:

Takut, gerogi. Awalnya itu kan sudah disusun dengan baik sentences toh, kase sesuai ini begini tapi pas mau diutarakan jadi baku tukar depe grammar...(Stud2:36)

Scare and nervous. Initially the sentence has been arranged well, it adjusts to it but when I want to say the grammar it becomes random... (Researchers' translation, Stud2:36)

Similarly, Stud8 said that she was rare to interact with ENSL because afraid of making mistake in using grammar:

kalo saya, tidak terlalu sering karna itu. takut saya bertanya... kurang kage grammarnya salah jadi masih ragu-ragu begitu kalo mau bertanya (Stud8:69)

For me, it is rare because of that... I am afraid to ask, I am afraid the grammar is wrong so I'm still hesitating if I want to ask (Researchers' translation, Stud8:69) 
Stud13 added that she was afraid of making mistake in using grammar because it will cause ENSL misunderstanding:

...takutnya itu nanti salah grammarnya jadi artinya juga akan salah sama Miss, jadi nanti terjadi misunderstanding (Stud13:120)

...I am afraid that the grammar would be incorrect so the meaning would be wrong by Miss, and then it would be a misunderstanding (Researchers' translation, Stud13:120)

Additionally, stud12 explained that she felt fear to interact with ENSL caused by lack of vocabulary and making mistake in pronouncing words:

iya, sama dengan sebelumnya. Kekurangan vocab dan kalo ada yang ingin ditanyakan sama Miss itu takut salah pronounce (Stud12:121)

Yes, similar to my friend before. Lack of vocabulary and I am afraid if the pronunciation would be wrong while I ask to Miss (Researchers'translation, Stud12:121)

These participants' responses reported that English incompetence is one of the factors that cause students to feel anxious when interacting with ENSL in the classroom. Making mistake in the aspects, such as vocabulary, grammar, and pronunciation, are the cause of students' anxious feeling and by doing so, misunderstanding between students with ENSL might occur. In further analysis regarding students perceived anxiety factor, misunderstanding is what they fear the most.

English inefficiency in grammar and pronunciation aspects also can affect students to feel anxious when interacting with ENS lecturer in the classroom. For example, Stud8 admitted that she is rare to ask to ENS lecturer because she was afraid if the grammar incorrect. It is in line with Stud12 reported that she felt anxious to ask to ENS because the pronunciation is at fault.

English proficiency can affect students' anxiety. This refers to English vocabulary, grammar and pronunciation. The students tend to fear of making mistake in those aspects. Thus, this theme is also due to fear of fear of negative evaluation factor. Students fear of making mistakes in English aspect because of possibly judgment from peers and English native speaker lecturer. Ahmed, Pathan, and Khan (2017) stated that the cause of fear of communicating with foreign language instructors is because they are afraid of committing grammatical errors. Thus, students tend to hesitate or even feel anxious when interact to ENS lecturer in the classroom. In addition, according to Kun-huei Wu (2010) as cited in Batiha, Noor, and Mustaffa (2014), the major factor which has role in Taiwanese students' performance and anxiety level is English proficiency.

\section{FEAR OF BEING MISUNDERSTOOD}

Fear of being misunderstood is another factor that triggers the anxiety in interaction between the participants and English native speaker in the classroom. For example, Stud7 reported that she was afraid if the ENSL misunderstand with her intention:

...takut dia salah paham begitu apalagi tidak bisa menjelaskan pake bahasa Indonesia kan (Stud7:81)

I'm afraid if she will misunderstand by what I'm saying especially I cannot explain by using Indonesia language (Researchers' translation, Stud7:81) 
Then Stud14 added that she was anxious if the ENSL did not get the point of her talking about: kalo saya takut salah misalnya bertanya tentang ini tapi Miss tangkapnya soal yang lain jadi misunderstanding. Begitu sih (Stud14:119)

I am afraid of making mistake, for example if I ask about this but Miss catches the other issues thus it would be misunderstanding (Researchers translation, Stud14:119)

In other case, Stud11 admitted that she felt nervous if she did not understand with what the ENSL said and found it hard to response:

....karena kurang paham dengan apa yang dikatakan oleh Miss jadi ee.. apa dulu... ee susah untuk merespon (Stud1 1:102)

......because lack of understanding of what was said by Miss, so it's hard to respond (Researchers' translation, Stud11:102)

Those responses above showed that fear of being misunderstood is one of factor that was revealed by the students as their anxiety factor when interacting with ENSL in the classroom. Another factor that the participants reported to have anxiety when interacting with English native speaker lecturer is lack of self-confidence.

From the finding, there are two data reported that they are fear when interact to ENS lecturer then she does not understand what their mean in English. It seems that anxiety can occur when the student concern to the meaning while speaking. Gass and Selinker (2001) supports to this finding as they stated that student can directly feel anxious because of deeply focus on the level of understanding.

\section{LACK OF SELF-SONFIDENCE}

Self-confidence is the next factor that prevents students to speak confidently. Correlated to the lack of confidence issue, Stud10 admitted that he has lower ability in English proficiency between his classmates.

kalo dari saya sendiri, mungkin kalo dari teman-teman semua saya itu saya.. yang punya skill paling dibawahlah jadii yang paling takut itu, takut salah grammar... (Stud10:78)

For myself, maybe from all my classmates, I have low skill in English soI fearful of that, fear if my grammar incorrect... (Researchers'translation, Stud10:78)

From the statement of Stud10, the researcher perceived that Stud10 lacked of confidence because he compared his ability in English with his classmates. Then, because he had assumed that his classmates were doing better than he did, thus, their appearance was ideal for him. Also lack of self-confidence is relevant to limited English proficiency factor. For example, Stud1 being not confident to speak with ENS lecturer because of vocabulary they have, then there will be interaction if ENSL asked them.

Kalo saya ada sedikit rasa takut karna ee.. vocab yang saya miliki itu emm.. Masih sedikit belum terlalu ini. jadi kalo bicara sama miss ituagak rada rada gimana gitu. Biasanya sih interaksi itu ada kalo missbertanya sama saya (Studl:23) 
I have anxiety because ee.. The vocabulary that I have emm.. It's still not much.. So if I was talking to Miss, it's like.. usually, there will beinteraction if Miss asking to me (Researchers' translation, Stud1:23)

Similar to Stud8 not confident to ask to ENSL in the classroom because she reported that she still hesitate to speak with ENSL because she was not sure if she had used grammar correctly or not. Furthermore, the third data have been proven that one of the anxiety factors when interacting with an ENSL, namely lack of self-confidence. Then, the last factor of students perceived anxiety factor is fear of negative evaluation.

As Maclntyre and Gardner (1994), environment where there exist multi-cultural and foreign speakers can increase the level of students' anxiety. Thus, it could impact of students' confidence in learning foreign language. Students with lack of self-confidence usually have an idealistic level of their performance. Thus, they will perceive that any performance of a lower level as unacceptable then it can provoke students' anxiety. It is clear the student feel that others in the class perform better than he does in terms of interaction with ENS lecturer. In fact, his classmates being his standard in speaking English instead of him does not. Also this is similar to the previous study by Ismail (2011), who found that lack of confidence is one of the students' problem related to their anxiety in speaking English.

According to Batiha, Noor, and Mustaffa (2014), students who are affected by their idealistic level of performance will leads to lack of self-confidence therefore provoke anxiety. It can be assume that students has suffer anxiety because lack of self-confidence behind of fear of making mistake in grammar. Also some students reported that they felt nervous and hesitate to interact with ENS lecturer. It seems they were not confident to interact with ENS lecturer.

\section{FEAR OF NEGATIVE EVALUATION}

Fear of negative evaluation means a sensitive feeling of a student to others evaluation. With regard to the peer evaluation issue, Stud15 explained that when he interacted with ENSL in the classroom, he was embarrassed with his classmates' judgment:

...agak malu sama teman-teman sih, nanti dibilang 'ih sok-sok bicara sama native' begitu kak (Stud15:105)

... I am little bit embarrassed to my friends, because they would said that I am pretending to talk with native (Researchers' translation, Stud15:105)

In another case, Stud3 stated that she was anxious that ENSL would give her opinions on her grammar while interaction:

...saya juga ada kayak anxiety begitu, ada rasa cemas kayak 'kira-kira Miss mau menjudge grammar saya tidak ee' saya lebih memikirkan judgment orang terhadap saya. Begitu kak (Stud3:37)

...I also have anxiety, there is anxiety like I thought wheter Miss wants to judge my grammar or not' I more concern about people's judgment on me. Like that (Researchers' translation, Stud3:37) 
These students responses reported that fear of negative evaluation are also being anxiety factor when interacting with an ENSL in the classroom. They are worry about judgment of their peers and ENSL itself.

Judgment from other whether peers or lecturer make students tend to feel worry when interact to ENS lecturer in the classroom. Fear of negative evaluation as a factor of foreign language classroom anxiety was defined by Horwitz, Horwitz, and Cope (1986) as the apprehension about other evaluations, avoidance of evaluative situations and the expectation that other would evaluate oneself negatively. For example, Stud15 asserted that he feel shy when interact to ENS lecturer because he is worry if his classmates would tell him that he is ostentatious. It shows that student concern about the negative evaluation factor. Thus, this factor can give impact to student to well-prepared before speaking in the classroom. Also as admission Stud15 that before interact to ENS lecturer he will write what he would say especially for the grammar structure. It is also to avoid negative evaluation from neither peers nor ENS lecturer itself.

\section{CONCLUSION}

This study was carried out at Universitas Negeri Gorontalo, in English Department. A qualitative method was employed and group interviews were done to collect data. Also thematic analysis was used to analyze the data and grouping into theme. Based on the result of analyzing data interview, this study successfully answered the research question by finding four themes which are factors that cause students to feel anxious, they are, limited English proficiency, fear of being misunderstood, lack of self-confidence, and fear of negative evaluation. This study revealed that English native speaker lecturer has minor influence in students' anxiety.

In addition, this study revealed that attitude or behavior of teacher in this case is English native speaker has influential on the level of students' anxiety. Also, this study found that students' anxiety decrease in overtime because the approach taken by English native speaker both emotionally and technically in teaching in the classroom. Besides, the English competence is a big impact to students' anxiety. It can be seen from the symptoms they suffer when they interact with English native speaker lecturer, they feel shaky, nervous, and sweaty because they are fear of making mistakes in neither pronunciation nor grammar. However, the current study concluded that beside the other factor, limited English proficiency as the factor that most significant relevant to students' anxiety in interacting orally with an English native speaker lecturer in the classroom.

Finally, the findings of the present study have confirmed that anxiety is a problem among English department students that must be recognized as important in learning foreign language. Thus, it is urgent for English lecturers to carry out some investigation in order to know about students' anxiety. Also it is necessary for lecturer to apply appropriate strategies to help them respond to this feeling and enhance the English teaching efficiency.

\section{REFERENCES}

Abid. (2018). Indonesian Pre-Service English Teachers' Perceived Challenges in Improving English Oral Communication Skills. Journal of English Education and Linguistics Studies, 5(2), 147-170. Retrieved from www.researchgate.netS

Batiha, J., Noor, N. M., \& Mustaffa, R. (2014). Exploring the Factors of Classroom Anxiety in The Context of EFL Arab Students. International Journal of Science and Humanities Research, 2(2), 18-31. Retrieved from http://www.researchpublish.com 
Bozavli, E., \& Gulmez, R. (2012). Turkish Students' Perspectives on Speaking Anxiety in Native and Non-Native English Speaker Classes. US-China Education Review, 12, 1034-1043. Retrieved from. https://files.eric.ed.gov/fulltext/ED539787.pdf

Clement, R. (1980). Ethnicity, Contact and Communicative Competence in a Second Language. Social Psychology and Language. Retrieved from https://www.researchgate.net/

Davies, A. (1991). The Native Speaker in Applied Linguistics. Edinburgh: Edinburgh University Press. Rertrieved from https://books.google.co.id/

Davies, A. (2013). The Native Speaker : Myth and Reality. Clevedon, UK: Multilingual Matters. Retrieved from https://www.academia.edu/

Gass, S. M., \& Selinker, L. (2001). Second Language Acquisition, an Introductory Course (2nd ed). Mahwah, New Jersey: Lawrence Erlbaum Associates.Retrieved from https://www.researchgate.net/

Gurkan, S., \& Yuksel, D. (2012). Evaluating The Contributions of Native and Non-Native Teachers to an English Language Teaching Program. Social and Behavioral Science, 46, 2951-2958. Retrieved from https://www.researchgate.net

Horwitz, E. K., Horwitz, M. B., \& Cope, J. (1986). Foreign Language Classroom Anxiety. The Modern Language Journal. 70(2). 125-132.

Lengkanawati, N. S. (2004). How Learners From Different Cultural Backgrounds Learn a Foreign Language. Asian EFL Journal, 6(1), 1-8.

Machmud, K., \& Abdulah, R. (2017). Using Smartphone-Integrated Model of Teaching to Overcome Students' Spekaing Anxiety in Learning English as a Foreign Language. Journal of Arts and Humanities, 6(9), 1-11. Retrieved from https://www.researchgate.net

MacIntyre, P. D., \& Gardner, R. C. (1991). Investigating Language Class Anxiety Using the Focused Essay Technique. The Modern Language Journal, 75, 296-304. Retrieved from http://faculty.cbu.ca/

MacIntyre, P. D., \& Gardner, R. C. (1994). The Subtle Effects of Language Anxiety on Cognitive Processing in The Second Language . Language Learning, 4(22), 283-305.

Mahmoodzadeh, M. (2012). Investigating Foreign Language Speaking Anxiety within the EFL Learner's Interlanguage System: The Case of Iranian Learners. Language Teaching and Research, 3(3), 466-476. Retrieved from http://www.academypublication.com/issues/past/jltr/vol03/03/16.pdf (Arnold, 2006)

Mbato, C. (2013). Facilitating Efl Learners' Self Regulation in Reading: Implementing a Metacognitive. Southern Cross University. Retrieved from https://epubs.scu.edu.au/theses/353/

Stocker, S. R. (2013). The Many Faces of Anxiety. USA: Holy Macro! Books.

Wiramihardja, S. A. (2005). Pengantar Psikologi Abnormal. Bandung: PT. Refika Aditama. Retrieved from http://library.um.ac.id/ 